\title{
Groundwater Quality Assessment in Ebubu Community, Eleme, Rivers State, Nigeria
}

Ikubor Austin Sokpuwu*

Department of Chemistry, Faculty of Science, University of Uyo, Uyo, Akwa Ibom State, Nigeria

*Corresponding author: Ikubor Austin Sokpuwu, Department of Chemistry, Faculty of Science, University of Uyo, Uyo, Akwa Ibom State, Nigeria, Tel: 08172388851; Email: aust_royal@yahoo.co.uk

Received date: December 20, 2017; Accepted date: December 26, 2017; Published date: December 29, 2017

Copyright: ( 2017 Sokpuwu IA. This is an open-access article distributed under the terms of the Creative Commons Attribution License, which permits unrestricted use, distribution, and reproduction in any medium, provided the original author and source are credited.

\begin{abstract}
This study was carried out to assess the drinking water quality of Ebubu community in Eleme between June 2015 and August 2015. Water samples were collected from ten functional boreholes using standard techniques. Physicochemical parameters ( $\mathrm{pH}$, electrical conductivity, TDS, Total hardness, Biochemical Oxygen Demand (BOD), Chemical Oxygen Demand (COD), Bicarbonate, Carbonate, Chloride, Nitrate, Phosphate, Sulphate, Magnesium, Potassium, Sodium and Calcium), toxic metals ( $\mathrm{Cd}, \mathrm{Pb}, \mathrm{Ni}$ and $\mathrm{Co}$ ) and Polyaromatic Hydrocarbons (PAHs) levels were assessed using standard analytical protocols. Values recorded for physicochemical parameters (except for Magnesium and Calcium) were within the World Health Organization (WHO) limits. All elements under study were detected at the ten locations. The mean value of Cadmium $(0.361 \pm 0.381 \mathrm{mg} / \mathrm{L})$ was observed to be the highest of all heavy metals assayed. The levels of the heavy metals in the study area were found to be in the order: Cadmium $(0.361 \pm 0.381 \mathrm{mg} / \mathrm{L})>$ Lead $(0.117 \pm 0.056 \mathrm{mg} / \mathrm{L})>$ Nickel $(0.042 \pm 0.0281 \mathrm{mg} / \mathrm{L})>$ Cobalt $(0.010 \pm 0.009 \mathrm{mg} / \mathrm{L})$ in the water samples. These values were above the WHO and NIS limits. PAHs were all $<0.01 \mathrm{mg} / \mathrm{L}$. The water quality parameters varied across the sampling periods (June and August); apart from $\mathrm{Cd}$ whose mean value was higher during the month of June, but lower during the month of August, all other toxic metals $(\mathrm{Ni}, \mathrm{Pb}$, and $\mathrm{Co}$ ) and physicochemical properties were higher during the month of August. The groundwater from the community is therefore, unsafe for drinking purpose due to elevated levels of toxic metals. In light of these findings, periodic analysis of samples from boreholes is inevitable. Such analysis will reveal pollution status of groundwater in this area and to determine the best method for water treatment, to intimate consumers and other users of the groundwater, and also to safeguard their health against the subsequent impact that may arise from drinking polluted water.
\end{abstract}

Keywords: Groundwater; Pollution; Heavy metals; Water quality

\section{Abbreviations:}

BOD: Biochemical Oxygen Demand; COD: Chemical Oxygen Demand; PAHs: Polyaromatic Hydrocarbons; WHO: World Health Organization; NIS: Nigerian Industrial Standard.

\section{Introduction}

The World Health Organization (WHO) [1] reported that 786 million people in the world do not have access to safe drinking water. This is roughly one in ten of the 7.4 billion world's population. Nigeria is not exempted from the world water crisis which is affecting other countries in many parts of the world. www.wateraid.org/waterfacts and figures/2016 [2] reported that over 63 million Nigerians have no choice but to get water wherever they can, leading to 57 million people not having access to safe water and 25,000 children die every year from diarrhea caused by unsafe water and poor sanitation.

Presently, it is estimated that more than 300 million people in Africa live in a water-scarce environment. By 2025, eighteen African countries are expected to experience water stress. The amount of freshwater available for each person in Africa is about one-quarter of what it was in 1950; in many countries, requirements for domestic freshwater use, sanitation, industry and agriculture cannot be met [3]. The situation might get worse as a consequence of population growth, rapid urbanization, increasing agriculture and industrial activities, and lack of adequate capacity to manage freshwater resources [3].

The best standard of purity is required for drinking water as the water we drink is got from different sources like wells, streams, lakes, rivers (surface water), groundwater (boreholes) [4]. Groundwater is water located beneath the surface in soil pore spaces and in permeable geological formations. Adeyemi [5] and Sule [6] gave empirical figures which suggest high groundwater resources potential for Nigeria. Olayinka and Adebayo [7] opined that the nation's groundwater resource is abundant and of good quality, estimated at 52,000 Million Cubic Metres (MCM), while MacDonald and Taylor [8] gave a best estimate of $11,800 \mathrm{~km}^{3}$ as estimated groundwater storage in Nigeria. Groundwater includes all water found beneath the earth's surface in a saturated zone of the aquifer [9]. They are formations that contain sufficient saturated permeable materials to yield sufficient quantities of water to wells and springs $[9,10]$. Groundwater can be extracted by means of Hand Dug Wells (HDWs) and boreholes at various depths. A large percentage of the world population depends on groundwater as their main source of drinking water [9,11-13].

Groundwater has various advantages over surface water as it is not exposed to water pollutants associated with surface waters. It is in view of this that the WHO recommended that drinking water supplies should be well analyzed based on their contamination or pollution level $[4,14]$. Very few people in small towns have access to safe water supply. Only about 5 percent get water from protected ground sources through boreholes $[4,15]$. The WHO had stated that it is not sufficient 
merely to have access to water in adequate quantities, the water also needed to be of adequate quality to maintain good health [15]. Such water must be free from toxic biological, physiological and chemical contaminations. The widespread reports on pollutants in groundwater have increased in recent years and have resulted in increased public concern about the quality of groundwater. The importance of potable water, both for domestic and industrial uses, has created concern for water quality analysis [4,16]. The compounds contained in groundwater, sometimes used as drinking water, are dangerous to human health because of the possibility of a mutagenic and carcinogenic reaction [17,18]. Groundwater bodies are prone to contamination from both anthropogenic and natural activities [19]. Boreholes, though more protected as a result of inherent chemical constituents of permeable rocks through which the water flows [20] can limit the quality of the water as they may have dissolved impurities which came from rock and sand strata through which the water flowed or passed. The seepage of waste buried underground such as pit toilets or leachate from fertilizer applications and debris from erosion can produce harmful effects on ground water quality especially in Ebubu, as it is one of the areas in Rivers State with potential high flooding risk and the residents are mostly farmers. This study was carried out to determine the physicochemical properties along side with possible PAHs contamination of ten different boreholes spatially distributed in Ebubu community in order to assess the potability and usability of their borehole water as domestic water supply. Ebubu is chosen for this research as it is considered a crude oil overburdened site owning to previous oil-spill record in that area.

The aim of the research was to investigate groundwater quality (physicochemical parameters) of some selected functional boreholes in Ebubu community, Eleme, Rivers state, Nigeria. The result and findings of this research shall provide information on the effect of crude oil spill on groundwater even after years of its spillage.

\section{Materials and Methods}

Groundwater samples were collected from the different sampling locations within Ebubu community, and were transported in an ice cooler to Fugro international Laboratory, Port Harcouth, Rivers state. For physicochemical parameters white polyethylene bottles were used and for BOD bottles a $1 \mathrm{~L}$ brown glass stoppered type was employed. Samples for determination of trace amount of toxic metals were collected in white plastic containers. For the PAHs analysis, groundwater samples were collected in glass bottles of $2 \mathrm{~L}$.

The $\mathrm{pH}$ of water samples was determined in accordance with APHA $4500 \mathrm{H}^{+} \mathrm{B}$. This was done electrometrically with a multi-parameter data logger. Conductivity and Total dissolved solids of water samples were determined in accordance with APHA 2510A. This was done electrometrically with a multi-parameter data logger (multi 340i/set). Total Suspended Solids (TSS) content of the water samples was determined with a membrane filter apparatus, in accordance with APHA 2540D. A $100 \mathrm{ml}$ aliquot of the water sample was filtered through dried pre-weighed $0.45 \mu \mathrm{m}$ filter paper, through which clean distilled water was subsequently passed to remove salt. The filter was then oven dried at $105 \pm 5^{\circ} \mathrm{C}$ for one hour. After drying, the filter paper was cooled and weighed. The difference in filter weights before and after filtering was used to calculate the TSS.

The TSS content was calculated as follows:

TSS $(\mathrm{mg} / \mathrm{L})=(\mathrm{A}-\mathrm{B}) \times 1000 /$ Sample Volume $(\mathrm{ml})$
Where, $\mathrm{A}=$ =weight of filter paper $(\mathrm{mg})+$ residue $(\mathrm{mg})$; $\mathrm{B}=$ weight of filter paper (mg).

The hardness of water was determined in accordance with APHA 2340C. One $\mathrm{ml}$ of the buffer solution was added into $50 \mathrm{ml}$ of the sample in a $250 \mathrm{ml}$ conical flask. Two drops of the indicator solution was added while swirling the mixture and a wine red colour developed. Standard EDTA titrant was added slowly with stirring, until the reddish tinge disappeared and colour changed to sky blue. Blank analysis was carried out with distilled water using the above procedure.

\section{Hardness (EDTA) as $\mathrm{mg} \mathrm{CaCO} / \mathrm{L}=(\mathrm{A}-\mathrm{B}) \times \mathrm{M} \times 8 \times 1000 / \mathrm{S}$}

Where, $A=$ standard EDTA solution required for titration of the sample (ml); B=standard EDTA solution required for titration of the blank (ml); 100=molar mass of $\mathrm{CaCO}_{3} ; 1000=$ conversion factor to litre.

BOD was determined in accordance with APHA 5210D. This was done respirometrically with WTW OXITOP instrument in the presence of Sodium hydroxide tablet and $\mathrm{N}$-allylthiourea solution. The samples were later measured into BOD sample incubation bottles with magnetic stirrer inserted in each sample bottle. The bottles with tightly screwed pressure measuring heads were placed in the incubator thermostatic box on a switched-on stirrer platform and incubated at $20^{\circ} \mathrm{C} \pm 1{ }^{\circ} \mathrm{C}$ for 5 days. Then the measured values were read from the pressure head and appropriate calculation factor applied. The analysis results were reported in $\mathrm{mg} / \mathrm{L}$.

\section{$\mathrm{BOD}(\mathrm{mg} / \mathrm{L})=(\mathrm{D} 1-\mathrm{D} 2) / \mathrm{P}$}

Where, D1=Initial Sample Dissolved-Oxygen (DO) concentration (in $\mathrm{mg} / \mathrm{L}$ ); $\mathrm{D} 2=$ Sample $\mathrm{DO}$ (in $\mathrm{mg} / \mathrm{L}$ ) after 5 days; $\mathrm{P}=$ Decimal Volumetric fraction of sample used.

COD was determined titrimetrically. In this method, organic matter was oxidized to carbon dioxide using acid dichromate as the oxidizing agent and its consumption which is equivalent to COD concentration was measured by titrating against a standard Ferrous ammonium sulphate solution.

The COD was calculated as follows:

$\mathrm{COD}(\mathrm{mg} / \mathrm{L})=\mathrm{B}-\mathrm{S}(\mathrm{ml}) \times$ titrant molarity $\times 8 \times 1000 /$ Volume of sample $(\mathrm{ml})$

Where, $B=$ Titre for Blank; S=Titre for Sample; 8=Atomic mass of Oxygen; $1000=$ Conversion to litre.

Carbonate and Bicarbonate were analysed in accordance with APHA 2320B test method used for determination of total alkalinity. A 0.1 M Hydrochloric acid $(\mathrm{HCl})$ stock solution was first prepared then diluted to a working solution of $0.01 \mathrm{M} .100 \mathrm{ml}$ of each sample was measured into a conical flask and 2-3 drops of phenolphthalein indicator was added wisely as the flask was swirled until a stable colour change to pink was observed. Based on alkalinity relationships, Carbonates and Bicarbonates were calculated.

Chloride was determined in accordance with APHA 4500- $\mathrm{Cl}^{-}$. This was done following Mohr procedure for determining Chloride ion with Silver nitrate. The Chloride reacts with Silver ion before any Silver chromate forms due to the lower solubility of Chloride. The Potassium chromate indicator reacted with excess Silver ion to form a red Silver chromate precipitate. The end point is the appearance of the first permanent brick red colour.

$\mathrm{Cl}^{-}(\mathrm{mg} / \mathrm{L})=\mathrm{Vs}-\mathrm{Vb}(\mathrm{ml}) \times$ titrant molarity $\times 35.45 \times 1000 /$ Volume of sample (ml) 
Page 3 of 11

Where, Vs=Volume of $\mathrm{AgNO}_{3}$ for sample; $\mathrm{Vb}=$ Volume of $\mathrm{AgNO}_{3}$ for blank; 35.45=Molar mass of $\mathrm{Cl}$; 1000=Conversion to litre.

Nitrate analysis in water was done colorimetrically based on EPA 352.1 method, using UV/Visible Spectrophotometer. One $\mathrm{ml}$ of each of the samples was analyzed directly using Brucine sulphate as a complexing agent in the presence of Sulphuric acid, and measured at a wavelength of $420 \mathrm{~nm}$.

$\mathrm{NO}_{3}^{-}(\mathrm{mg} / \mathrm{L})=\mathrm{mg}\left(\mathrm{NO}_{3}{ }^{-}\right)$in sample from calibration graph-mg $\left(\mathrm{NO}_{3}^{-}\right)$in blank

The APHA 4500- $\mathrm{SO}_{4}{ }^{2-}$-E method (Visible Light Method), described in the Standard Method for Examination of Water and Wastewater (1998) which is turbiditimetric, was used to determine the Sulphate $\left(\mathrm{SO}_{4}{ }^{2-}\right)$. With the addition of Barium chloride, Barium sulphate was formed giving the turbidity that is measured. $\mathrm{SO}_{4}{ }^{2-}$ was calculated as follows:

\section{$\mathrm{SO}_{4}{ }^{2-}(\mathrm{mg} / \mathrm{L})=\mathrm{A}-\mathrm{B} /$ Sample volume $(\mathrm{ml})$}

Where, $\mathrm{A}=$ Volume of $\mathrm{H}_{2} \mathrm{SO}_{4}$ titrated for sample $(\mathrm{mg} / \mathrm{L})$; $\mathrm{B}=$ Volume of $\mathrm{H}_{2} \mathrm{SO}_{4}$ titrated for blank (mg/L).

Phosphate was determined in accordance with APHA 4500 PD 20th Edition 2003, a colorimetric method which is based on a blue complex induced by the addition of stannous Chloride. Each sample was analyzed at a wavelength of $690 \mathrm{~nm}$ with UV/Visible Spectrophotometer.

Phosphate $(\mathrm{mg} / \mathrm{L})$ content was calculated as follows:

$\mathrm{PO}_{4}{ }^{3-}=\mathrm{mg} \mathrm{PO}_{4}{ }^{3-}$ (in approximately $104 \mathrm{ml}$ final volume $) \times 1000 /$ Sample volume $(\mathrm{ml})$

Heavy metals were determined in accordance with APHA 3111B, 3112B, 3114B, 3030B and ASTM D3859 (Appendix 2) [21]. Samples of groundwater obtained from Ebubu Eleme were subjected to atomic absorption spectrometer (Perkin Elmer 3100 model) for metals analyses. $\mathrm{Pb}, \mathrm{Cd}, \mathrm{Ni}$ and $\mathrm{Co}$ was analysed.

Heavy metal contents were calculated as follows:

\section{Metal concentrations $(\mathrm{mg} / \mathrm{L})=\mathrm{C} \times \mathrm{Y} / \mathrm{X}$}

Where, $\mathrm{C}=\quad$ Concentration of metal determined from calibration curve $(\mathrm{mg} / \mathrm{L})$; Y=Final volume made up $(\mathrm{ml}) ; \mathrm{X}=$ Volume of sample (ml).

\section{Polyaromatic hydrocarbon in water samples}

The Gas Chromatography (USEPA 8270) test method was adopted using GC/FID. Sterile amber coloured bottles were used to collect borehole water samples and fixed with concentrated $\mathrm{H}_{2} \mathrm{SO}_{4}$. Samples were transferred to the laboratory in iced coolers and analyzed using Gas chromatography coupled with Flame Ionization Detector (GCFID). Sample extraction was effected by Liquid-liquid Extraction in a separating funnel using Dichloromethane (DCM) as solvent. The sample extract was subsequently iltered through glass wool containing anhydrous Sodium sulphate in a glass funnel. This was followed by clean-up and separations via a Solid Phase Extraction (SPE) column packed with silica gel. The PAH fraction of the extract (eluted with DCM/Hexane mixture) was allowed to concentrate to $1 \mathrm{ml}$, transferred into the vials and analyzed using Agilent 7890A GC/FID previously calibrated with PAH standards under specific temperature programmed inlet, oven and detector conditions.

\section{Results and Discussion}

The $\mathrm{pH}$ values of groundwater samples in Ebubu community indicates acidity, and were lower than the permissible limit prescribed by WHO [22] and NIS [23]. The acidity may have resulted from landfill gases arising from the decomposition of waste materials from existing dumpsites around the community [24]. More so, acid rain resulting from gas flaring within the region infiltrates through the soil to the aquifer thereby reducing the $\mathrm{pH}$ value and making it more acidic [25]. High $\mathrm{pH}$ value induces the formation of trihalomethanes, which are toxic, while $\mathrm{pH}$ below 6.5 initiates corrosion in pipes thereby releasing toxic metals such as Zinc, Lead, Cadmium and Copper [26]. Akuro [24] noted that the groundwater around Eleme town, Rivers State had a $\mathrm{pH}$ value range of 4.34-5.34 in agreement with the observations made in this study.

The maximum limit of EC in drinking water as prescribed by NIS is $1000 \mu \mathrm{s} / \mathrm{cm}$. The value recorded from Ebubu community falls within the WHO and NIS acceptable limit (Table 1). Fashola [27] had reported an EC value that ranged from $236-717 \mu \mathrm{s} / \mathrm{cm}$, with an average of $47.63 \mu \mathrm{s} / \mathrm{cm}$ in a study conducted in old Port Harcourt Township, Eastern Niger Delta, which agrees with the finding from the present study. The relatively low EC values obtained in this present study is an indication of the absence of objectionable tastes in the water [24].

\begin{tabular}{|l|l|l|l|l|l|l|l|l|l|l|l|l|l|}
\hline \multicolumn{1}{|l}{ Sample locations } \\
\hline Parameters & BH1 & BH2 & BH3 & BH4 & BH5 & BH6 & BH7 & BH8 & BH9 & BH10 & MEAN & WHO (2006) & NIS (2007) \\
\hline pH & 5.75 & 5.77 & 5.08 & 4.99 & 4.71 & 4.83 & 4.19 & 4.15 & 5.58 & 5.42 & $5.05 \pm 0.59$ & $6.5-8.5$ & $6.5-8.5$ \\
\hline EC $(\mu \mathrm{S} / \mathrm{cm})$ & 263.5 & 260.5 & 236.5 & 234.5 & 82.2 & 81.15 & 137.5 & 138 & 262 & 81 & $\begin{array}{l}177.69 \\
83.54\end{array}$ & NS & 1000 \\
\hline TDS $(\mathrm{mg} / \mathrm{L})$ & 158.2 & 156.4 & 142 & 140.5 & 49.3 & 48.7 & 82.5 & 82.8 & 156.5 & 48.1 & 40.54 & \pm & 500 \\
\hline TSS $(\mathrm{mg} / \mathrm{L})$ & $<1.00$ & $<1.00$ & $<1.00$ & $<1.00$ & $<1.00$ & $<1.00$ & $<1.00$ & $<1.00$ & $<1.00$ & $<1.00$ & ND \pm ND & NS & 500 \\
\hline TH $(\mathrm{mg} / \mathrm{L})$ & 62.5 & 60 & 55 & 53.5 & 18 & 13.5 & 24.5 & 23.95 & 57.9 & 24 & $39.29 \pm 19.91$ & NS & NS \\
\hline BOD $(\mathrm{mg} / \mathrm{L})$ & 10 & 5 & 5 & 5.25 & 5 & 15 & 10 & ND & 5 & 5 & $6.53 \pm 3.61$ & 10 & NS \\
\hline COD $(\mathrm{mg} / \mathrm{L})$ & 21.75 & 10.65 & ND & 7.95 & ND & 11.45 & ND & ND & 10.4 & 11.6 & $7.38 \pm 4.81$ & 40 & NS \\
\hline
\end{tabular}


Table 1: Mean distribution of physiochemical properties of the analyzed groundwater samples.

The average level of total hardness is $39.29 \mathrm{mg} / \mathrm{L}$ and agrees with report by Nwankwo and Igbokwe [25] on groundwater within Choba area of Rivers State. Based on Freeze and Cherry's [28] classification of hardness in groundwater, the water from Ebubu Town can be classified as soft. The water in the area is, therefore, soft and requires No treatment for domestic use. There is no set maximum limit of total hardness in drinking water prescribed by WHO and NIS (Table 1) [21,22].

The average value recorded for total dissolved solids was $106.5 \mathrm{mg} / \mathrm{L}$ (Table 1). According to WHO and the NIS, the desirable limit of TDS is $500 \mathrm{mg} / \mathrm{L}$ and values from all samples in this study were below the standard permissible limit (Table 1). These low values obtained in this present study are an indication of the presence of low impurities in the groundwater [29]. These authors had reported groundwater with total dissolved solids concentrations up to $1250 \mathrm{mg} / \mathrm{L}$ in the coastal part of the Niger Delta.

The groundwater sampled from Ebubu community could be said to be non-saline, supported by the findings of Fashola, Nwankwoala and Tse [27]. They reported a TDS value ranging between 150 and 375 $\mathrm{mg} / \mathrm{L}$ with an average of $250 \mathrm{mg} / \mathrm{L}$ within the Niger Delta area, and far below the maximum value of $1000 \mathrm{mg} / \mathrm{L}$ recommended by the WHO and Nigeria Industrial Standard. There is no documented health effect of taking water with low TDS [30].

Although there is no set limit for TSS by the WHO and NIS, TSS values of $\mathrm{BH} 1$ to $\mathrm{BH} 10$ are all less than $1.00 \mathrm{mg} / \mathrm{L}$ and comparable with the findings of Nwankwola, Marshall and Oborie [31], who reported a low TSS value in groundwater within Rivers State.

The WHO [22] prescribed a maximum limit of $10 \mathrm{mg} / \mathrm{L}$ for BOD; the NIS [23] has no set limit. The values from this present study (Table
1) are slightly above the WHO permissible range values for drinking water. This is indicative of a slight pollution of the groundwater which may be attributed to percolations of hydrocarbon (crude oil) and other organic wastes [32].

The average COD value recorded was $7.38 \mathrm{mg} / \mathrm{L}$. The NIS (2007) has no set limit for COD, but the value obtained is within the WHO [22] permissible limit of $40 \mathrm{mg} / \mathrm{L}$ (Table 1) and is similar to the findings of Amangabara and Ejenma [3] who reported lower COD values within the Niger Delta region.

The average value of Bicarbonate from this study was $9.83 \mathrm{mg} / \mathrm{L}$. There is no set limit for Bicarbonate by WHO [22] and the NIS [23]. However, Edet, Nganje, Ukpong, et al. [33] reported a $\mathrm{HCO}_{3}^{-}$level of $71.50 \mathrm{mg} / \mathrm{L}$ within the Niger Delta area. According to Davis and Dewiest [34] Bicarbonate rarely exceeds $40-400 \mathrm{mg} / \mathrm{L}$ in groundwater. Bicarbonate helps to buffer lactic acid generated during exercise and also reduces the acidity of dietary components [35].

The values of Carbonate recorded from $\mathrm{BH} 1$ to $\mathrm{BH} 10$ were all less than $1.00 \mathrm{mg} / \mathrm{L}$. There are no set limits for Carbonate by the WHO and NIS [22,23]. However, Nwankwoala [31] obtained similar values ranging between 0.00-0.02 mg/L within Okrika, Rivers State, Nigeria.

The values of Chloride recorded in this study fall far below the WHO [22] and NIS [23] prescribed permissible limit of $250 \mathrm{mg} / \mathrm{L}$ for drinking water (Table 2). Udom [36] had suggested that Chloride contents greater than $40 \mathrm{mg} / \mathrm{L}$ in coastal areas indicate saltwater contamination. The findings from this present work agrees with the work of Fashola [27], who in their study of groundwater within Choba Area of Rivers State had reported a Chloride value of 56.00-86.00 $\mathrm{mg} / \mathrm{L}$; this was far below the WHO [22] limit of $250 \mathrm{mg} / \mathrm{L}$.

\begin{tabular}{|c|c|c|c|c|c|c|c|c|c|c|c|c|c|}
\hline \multicolumn{14}{|c|}{ Sample locations } \\
\hline Parameters & BH1 & BH2 & $\mathrm{BH} 3$ & BH4 & BH5 & BH6 & $\mathrm{BH} 7$ & BH8 & BH9 & BH10 & Mean & $\begin{array}{l}\text { WHO } \\
(2006)\end{array}$ & NIS (2007) \\
\hline $\mathrm{HCO}_{3}-(\mathrm{mg} / \mathrm{L})$ & 27.2 & 24.8 & 7.55 & 6.9 & ND & ND & ND & ND & 31.8 & ND & $\begin{array}{ll}9.83 & \pm \\
11.62 & \end{array}$ & NS & NS \\
\hline $\mathrm{CO}_{3}^{-}(\mathrm{mg} / \mathrm{L})$ & $<1.00$ & $<1.00$ & $<1.00$ & $<1.00$ & $<1.00$ & $<1.00$ & $<1.00$ & $<1.00$ & $<1.00$ & $<1.00$ & $N D \pm N D$ & - & - \\
\hline $\mathrm{Cl}^{-}(\mathrm{mg} / \mathrm{L})$ & 68.9 & 67.65 & 61.25 & 59.7 & 13.22 & 11.79 & 29.55 & 29.5 & 68.15 & 11.64 & $\begin{array}{l}42.14 \\
25.22\end{array}$ & 250 & 250 \\
\hline $\mathrm{NO}_{3}^{-}(\mathrm{mg} / \mathrm{L})$ & 17.32 & 15.59 & 12.42 & 19.32 & 23.17 & 18.07 & 16.72 & $<0.02$ & 18.46 & 19.07 & $\begin{array}{l}16.01 \quad \pm \\
2.93\end{array}$ & 10 & 50 \\
\hline $\mathrm{PO}_{4}(\mathrm{mg} / \mathrm{L})$ & 0.01 & 0.04 & ND & 0.04 & 0.06 & 0.03 & ND & 0.02 & 0.03 & 0.09 & $\begin{array}{l}0.03 \\
0.03\end{array}$ & 0.5 & NS \\
\hline $\mathrm{SO}_{4}{ }^{2}(\mathrm{mg} / \mathrm{L})$ & 11.4 & 11.3 & 10.15 & 9.85 & 2.75 & 2.56 & 5.27 & 5.18 & 10.79 & 2.4 & $\begin{array}{l}7.16 \\
3.88\end{array}$ & 250 & 100 \\
\hline
\end{tabular}

Table 2: Mean distribution of anions parameters of the analyzed groundwater samples. 
Page 5 of 11

The average value of $16.01 \mathrm{mg} / \mathrm{L}$ recorded for Nitrate in this study falls within the NIS [23] permissible limit. However, it exceeded the WHO [22] limit of $10 \mathrm{mg} / \mathrm{L}$ for potable water. This finding is similar to findings of Nwala, [37] Manilla and Tamuno-adoki [38]. Increased Nitrate content in drinking water can cause the formation of methaemoglobinaemia. This high value of Nitrate can be traced to the high incidence of surface waste dumps in the area [24]. Similar observations in respect to surface waste dumps and indiscriminate digging of pit latrines and soak-away in Niger Delta area have been reported [39]. With respect to Chloride and Nitrate, the levels of these contaminants had no linear relationship the closeness to the location of the septic tanks and the depth of the boreholes.

The average value of Phosphate recorded in this study was $0.03 \mathrm{mg} /$ L. This value falls within the WHO [22] set limit of $0.5 \mathrm{mg} / \mathrm{L}$. This inding is supported by previous work of Rim-Rukeh, Ikhifa, Okokoyo, et al. [40] who in their study of groundwater within the Niger Delta observed a low level of Phosphate in groundwater with a range of 0.89-1.12 mg/L. Sources of Phosphate include human sewage, agricultural run-off from crops, and sewage from animal feedlots within the community [41].
The average Sulphate value recorded in this study was $7.16 \mathrm{mg} / \mathrm{L}$ This value recorded falls Within the WHO [22] and NIS [23] limits of $250 \mathrm{mg} / \mathrm{L}$ and $100 \mathrm{mg} / \mathrm{L}$ respectively. The Findings from this study are similar to that of Fashola [27] who reported an average Sulphate value of $7.21 \mathrm{mg} / \mathrm{L}$ within the Old Port Harcourt Township. Although the values from this study are low, increase in Sulphate content could come from seawater intrusion, oxidation of sulphides, and from sulphurous lare gases discharged to atmosphere which o ten result in acid rainwater containing detectable levels of Sulphate in industrialized area like Eleme, where Ebubu community is situated [27].

The average value of Magnesium in the study area was $2.35 \mathrm{mg} / \mathrm{L}$ (Table 3). The values obtained for all the sampling points were above both the WHO [22] $(0.5 \mathrm{mg} / \mathrm{L})$ and the NIS [23] $(0.20 \mathrm{mg} / \mathrm{L})$ permissible limits for Magnesium in groundwater for drinking purposes. The values obtained for $\mathrm{Mg}^{2+}$ agree with the values reported by Bolaji and Tse [42] and NDES [43].

\begin{tabular}{|c|c|c|c|c|c|c|c|c|c|c|c|c|c|}
\hline \multicolumn{14}{|c|}{ Sample locations } \\
\hline Parameters & BH1 & BH2 & BH3 & BH4 & BH5 & BH6 & BH7 & BH8 & BH9 & BH10 & Mean & $\begin{array}{l}\text { WHO } \\
(2006)\end{array}$ & NIS (2007) \\
\hline $\mathrm{Mg}(\mathrm{mg} / \mathrm{L})$ & 2.88 & 3.36 & 3.39 & 3.39 & 1.37 & 1.22 & 1.86 & 1.84 & 2.88 & 1.29 & $\begin{array}{l}2.35 \\
0.92\end{array}$ & 0.5 & 0.2 \\
\hline $\mathrm{K}(\mathrm{mg} / \mathrm{L})$ & 6.41 & 6.46 & 4.55 & 4.22 & 1.94 & 1.87 & 3.85 & 3.8 & 6.92 & 2.02 & $\begin{array}{l}4.20 \\
1.92\end{array}$ & NS & NS \\
\hline $\mathrm{Na}(\mathrm{mg} / \mathrm{L})$ & 15.33 & 15.11 & 14.4 & 13.63 & 4.81 & 4.85 & 7.62 & 6.99 & 14.19 & 5.22 & $\begin{array}{l}10.21 \quad \pm \\
4.66\end{array}$ & 50 & 200 \\
\hline $\mathrm{Ca}(\mathrm{mg} / \mathrm{L})$ & 10.53 & 10.77 & 9.84 & 8.72 & 4.1 & 3.47 & 4.93 & 5.46 & 10.14 & 4.19 & $\begin{array}{ll}7.21 & \pm \\
3.03 & \end{array}$ & 0.1 & NS \\
\hline
\end{tabular}

Table 3: Mean distribution of cations parameters of the analyzed groundwater samples.

Average value of Potassium value was $4.20 \mathrm{mg} / \mathrm{L}$ (Table 3). The minimum value of $\mathrm{K}^{+}$is recorded in $\mathrm{BH} 6$, while the maximum value is recorded in $\mathrm{BH} 9$ and is similar to the mean value of $8.07 \mathrm{mg} / \mathrm{L}$ [33] reported within the Niger Delta region. However, no prescribed limits have been provided by both the WHO [22] and NIS [23].

An average level of $10.21 \mathrm{mg} / \mathrm{L}$ is recorded for Sodium in the study area. All samples analysed had Sodium values below the guideline values of $50 \mathrm{mg} / \mathrm{L}$ and $200 \mathrm{mg} / \mathrm{L}$ given by the WHO and the NIS, respectively. This inding is similar to that of Ugwu and Nwosu [44] who reported a lower Sodium value in groundwater around Choba area, Rivers State.

The average value of Calcium was $7.21 \mathrm{mg} / \mathrm{L}$ (Table 3). The minimum value was recorded in $\mathrm{BH} 6$ and the maximum in $\mathrm{BH} 2$. This value is lower than the WHO permissible limit of $150 \mathrm{mg} / \mathrm{L}$; there is no specified limit by NIS. The values obtained for $\mathrm{Ca}^{2+}$ agree with the values reported by Bolaji and Tse [42] and NDES [43].

Results obtained reveal that the major ions such as $\mathrm{Ca}^{2+}, \mathrm{Mg}^{2+}, \mathrm{Na}^{+}$, and $\mathrm{Cl}^{-}$were present in all the samples. However, the levels of these constituents are well below the acceptable standards recommended by the World Health Organization (WHO).
These metals were present in all the sampled boreholes, though their values varied. The presence of these metals is often characteristic of municipal landfill leachates and can be harmful to health [28]. The average value of nickel present in groundwater was $0.042 \mathrm{mg} / \mathrm{L}$ in groundwater. This value is higher than the WHO [22] and NIS [23] prescribed limit. The minimum value was obtained in BH5 and maximum in BH10. Nickel was however not detected at BH6, BH7 and BH8 (Table 4). The distribution of Nickel in groundwater is presented in Figure 1. Water samples from boreholes (BH6, BH7 and $\mathrm{BH} 8$ ) had the same pattern of distribution as their values were below the detection limit. Similarly, in the month of June, Ni level was below the detection level in BH5. Water samples from $\mathrm{BH} 10$ had the highest level of Nickel for both June and August (sampling periods) followed by water from $\mathrm{BH} 2$. The presence of Nickel is an indicator of the presence of pollution from petroleum product [45]. This finding is similar to that of Asubiojo, Nkono, Ogunsua, et al. [46] who in their study had values above the WHO limit within the Niger Delta area. However, this finding is at variance with Akpoveta, Okoh and Osakwe [47] who had values lower than the WHO [22] limit within the Niger Delta area. Nickel can result in lung, liver and kidney damage. In high quantities, 
$\mathrm{Ni}$ can also cause cancer, respiratory failure, birth defects, allergies, dermatitis, eczema, nervous system and heart failure [48].

\begin{tabular}{|c|c|c|c|c|c|c|c|c|c|c|c|c|c|}
\hline \multicolumn{14}{|c|}{ Sample locations } \\
\hline Parameters & BH1 & BH2 & BH3 & BH4 & BH5 & BH6 & BH7 & BH8 & BH9 & BH10 & Mean & $\begin{array}{l}\text { WHO } \\
(2006)\end{array}$ & $\begin{array}{l}\text { NIS } \\
\text { (2007) }\end{array}$ \\
\hline $\mathrm{Ni}$ & 0.04 & 0.08 & 0.05 & 0.03 & 0.003 & BDL & BDL & BDL & 0.013 & 0.2 & $\begin{array}{l}0.042 \quad \pm \\
0.0281\end{array}$ & 0.07 & 0.02 \\
\hline $\mathrm{Cd}$ & 0.68 & 0.3 & 0.38 & 0.27 & 0.42 & 0.54 & 0.35 & 0.42 & 0.2 & 0.05 & $\begin{array}{l}0.361 \\
0.381\end{array}$ & 0.003 & 0.003 \\
\hline $\mathrm{Pb}$ & 0.11 & 0.18 & 0.09 & 0.09 & 0.1 & 0.11 & 0.09 & 0.12 & 0.15 & 0.13 & $\begin{array}{l}0.117 \\
0.056\end{array}$ & 0.01 & 0.01 \\
\hline Co & 0.01 & 0.02 & 0.01 & 0.005 & 0.01 & 0.004 & 0.01 & 0.0075 & 0.02 & 0.003 & $\begin{array}{l}0.010 \\
0.009\end{array}$ & 0.0038 & NS \\
\hline
\end{tabular}

Table 4: Mean distribution of toxic metals of the analyzed groundwater samples.

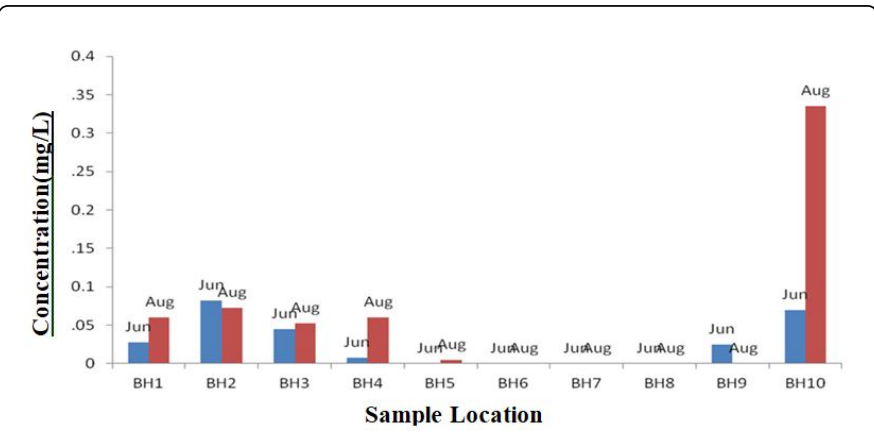

Figure 1: Monthly distribution of Nickel in boreholes from EbubuEleme.

Lead from this study had a mean value of $0.117 \mathrm{mg} / \mathrm{L}$ within the study area. This value is above both the WHO [22] and the NIS [23] limits of $0.01 \mathrm{mg} / \mathrm{L}$. These findings confirm an earlier work by Asubiojo [46] who had recorded a mean value of $2.8 \mathrm{mg} / \mathrm{L}$ in groundwater within this region, an indication of possible lead pollution with the study area. The distribution pattern of Lead in groundwater from Ebubu community is presented in Figure 2 indicates that water samples from boreholes ( $\mathrm{BH} 1$ to $\mathrm{BH} 8)$ had the same pattern of distribution as their values in the month of June were more than in the month of August. The reverse case was observed for BH9 and $\mathrm{BH} 10$ where the values in the month of August were higher than in the month of June. Although BH9 and BH10 are $768.56 \mathrm{~m}$ and $929.96 \mathrm{~m}$ away from the legacy spill site (Table 1), this could be due to more ionic dilution within the aquifer during the month of August. The peak value of lead content was recorded for $\mathrm{BH} 2$ first sampling. Lead in drinking water could have significant medical effects on renal functions [49]. Other symptoms of acute lead poisoning are headache, irritability, abdominal pain [50].

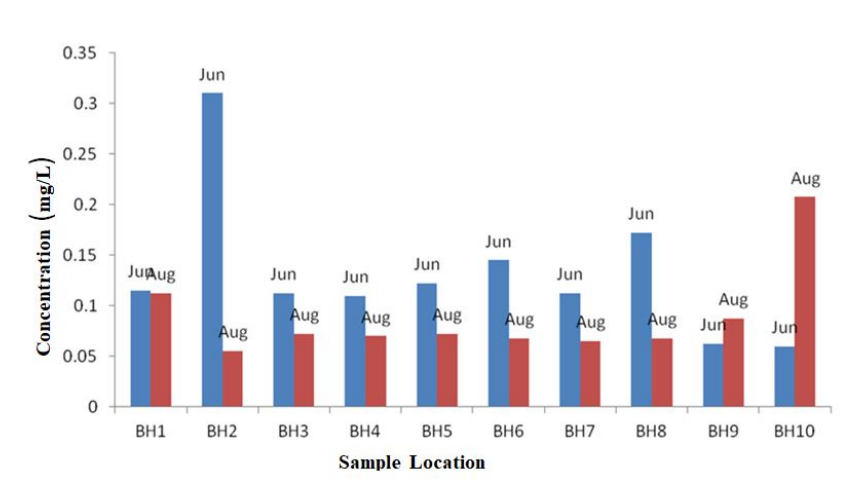

Figure 2: Monthly distribution of Lead in boreholes from EbubuEleme.

Cadmium had a mean level of $0.361 \mathrm{mg} / \mathrm{L}$ in this study (Table 4). This value is above the permissible limit of $0.003 \mathrm{mg} / \mathrm{L}$ prescribed by both the WHO and NIS [22,23]. Distribution pattern of Cadmium in groundwater is presented in Figure 3. Water samples from boreholes (BH1 to BH9) have more levels of Cadmium in the month of June than in the month of August (the second sampling period). However, in BH10 Cadmium was below detection level during the month of August. The finding from this study is however at variance with Uzoekwe and Oghosanine's [51] submission in their study conducted on water bodies around Warri refinery area in Nigeria, when they reported nil for Cadmium. However, cadmium has health effects like hypertension, cancer, cardiovascular diseases and other kidney related effects [52]. 


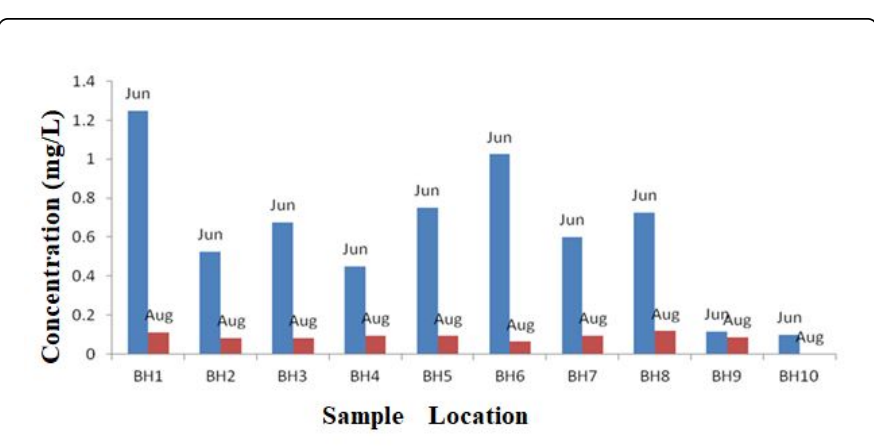

Figure 3: Monthly distribution of Cadmium in boreholes from Ebubu-Eleme.

The mean value of cobalt (Co) observed in this study was 0.010 $\mathrm{mg} / \mathrm{L}$. This is above the WHO value of $0.0038 \mathrm{mg} / \mathrm{L}$. This finding collaborates with Asubiojo [46] report that revealed a mean value of $0.60 \mathrm{mg} / \mathrm{L}$ within the same area. The distribution pattern of Cobalt in groundwater samples is presented in Figure 4. Cobalt was below detection limit in four boreholes (BH4, BH5, BH6 and $\mathrm{BH} 8$ ) in June, and $\mathrm{BH} 10$ only in August. However, Cobalt was detected in six boreholes (BH1, $\mathrm{BH} 2, \mathrm{BH} 3, \mathrm{BH} 7, \mathrm{BH} 9$, and $\mathrm{BH} 10)$ in June and nine boreholes (BH1, BH2, BH3, BH4, $\mathrm{BH} 5, \mathrm{BH} 6, \mathrm{BH} 7, \mathrm{BH} 8$ and $\mathrm{BH} 9)$ in August. The presence of $\mathrm{Co}$ is an indicator of the presence of pollution from petroleum product [45]. Cobalt, when ingested, could lead to vomiting, abdominal pain, allergic reactions in the skin, asthma, inflammation and fibrosis of the lung [22]. Generally, the higher contents of toxic metals recorded in this study indicate higher metal accumulation and this is similar to the findings of Ideriah, Briggs and Stanley [53] within the same region.

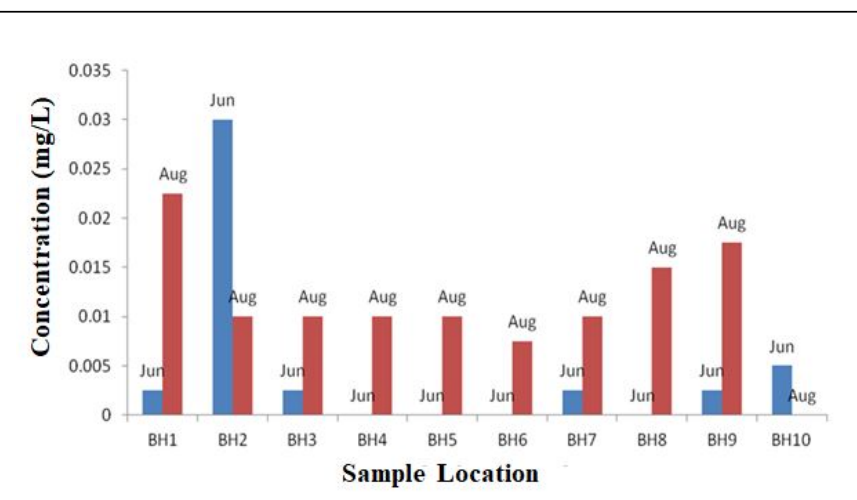

Figure 4: Monthly distribution of Cobalt in boreholes from EbubuEleme.

PAHs in groundwater samples from the study area were all less than $0.01 \mathrm{mg} / \mathrm{L}$ (Table 5), and are lower than the WHO maximum permissible limit for PAHs in drinking water $(0.002 \mathrm{mg} / \mathrm{L})$. This finding is similar to the report by Anyakora and Coker [54] on PAHs in groundwater within the Niger Delta region which revealed high molecular mass PAHs such as benzo(ghi)perylene, $\operatorname{dibenz}(\mathrm{a}, \mathrm{h})$ anthracene and indeno(1,2,3-cd)pyrene which were mostly absent confirming the low water solubility of these compounds.

\begin{tabular}{|c|c|c|c|c|c|c|c|c|c|c|c|}
\hline \multicolumn{12}{|l|}{ Sample locations } \\
\hline Parameters & WHO & NIS & BH1 & BH2 & BH3 & $\mathrm{BH} 4$ & BH5 & BH6 & $\mathrm{BH} 7$ & BH8 & BH9 \\
\hline Naphthalene & NS & NS & $<0.01$ & $<0.01$ & $<0.01$ & $<0.01$ & $<0.01$ & $<0.01$ & $<0.01$ & $<0.01$ & $<0.01$ \\
\hline 2-Methylnaphthalene & NS & NS & $<0.01$ & $<0.01$ & $<0.01$ & $<0.01$ & $<0.01$ & $<0.01$ & $<0.01$ & $<0.01$ & $<0.01$ \\
\hline Acenapthylene & NS & NS & $<0.01$ & $<0.01$ & $<0.01$ & $<0.01$ & $<0.01$ & $<0.01$ & $<0.01$ & $<0.01$ & $<0.01$ \\
\hline Acenaphthene & 0.2 & NS & $<0.01$ & $<0.01$ & $<0.01$ & $<0.01$ & $<0.01$ & $<0.01$ & $<0.01$ & $<0.01$ & $<0.01$ \\
\hline Fluorene & 0.3 & NS & $<0.01$ & $<0.01$ & $<0.01$ & $<0.01$ & $<0.01$ & $<0.01$ & $<0.01$ & $<0.01$ & $<0.01$ \\
\hline Phenanthrene & NS & NS & $<0.01$ & $<0.01$ & $<0.01$ & $<0.01$ & $<0.01$ & $<0.01$ & $<0.01$ & $<0.01$ & $<0.01$ \\
\hline Anthracene & NS & NS & $<0.01$ & $<0.01$ & $<0.01$ & $<0.01$ & $<0.01$ & $<0.01$ & $<0.01$ & $<0.01$ & $<0.01$ \\
\hline Fluoranthene & 0.3 & $2 \times 10-4$ & $<0.01$ & $<0.01$ & $<0.01$ & $<0.01$ & $<0.01$ & $<0.01$ & $<0.01$ & $<0.01$ & $<0.01$ \\
\hline Pyrene & 0.2 & NS & $<0.01$ & $<0.01$ & $<0.01$ & $<0.01$ & $<0.01$ & $<0.01$ & $<0.01$ & $<0.01$ & $<0.01$ \\
\hline Benzo(a)anthracene & $5 \times 10-5$ & NS & $<0.01$ & $<0.01$ & $<0.01$ & $<0.01$ & $<0.01$ & $<0.01$ & $<0.01$ & $<0.01$ & $<0.01$ \\
\hline Chrysene & $5 \times 10-3$ & NS & $<0.01$ & $<0.01$ & $<0.01$ & $<0.01$ & $<0.01$ & $<0.01$ & $<0.01$ & $<0.01$ & $<0.01$ \\
\hline Benzo(b)fluoranthene & $5 \times 10-5$ & $2 \times 10-4$ & $<0.01$ & $<0.01$ & $<0.01$ & $<0.01$ & $<0.01$ & $<0.01$ & $<0.01$ & $<0.01$ & $<0.01$ \\
\hline Benzo(k)fluoranthene & $5 \times 10-5$ & $2 \times 10-4$ & $<0.01$ & $<0.01$ & $<0.01$ & $<0.01$ & $<0.01$ & $<0.01$ & $<0.01$ & $<0.01$ & $<0.01$ \\
\hline Benzo(a)pyrene & $5 \times 10-6$ & $2 \times 10-4$ & $<0.01$ & $<0.01$ & $<0.01$ & $<0.01$ & $<0.01$ & $<0.01$ & $<0.01$ & $<0.01$ & $<0.01$ \\
\hline Dibenzo(a,h)anthracene & $5 \times 10-6$ & NS & $<0.01$ & $<0.01$ & $<0.01$ & $<0.01$ & $<0.01$ & $<0.01$ & $<0.01$ & $<0.01$ & $<0.01$ \\
\hline
\end{tabular}




\begin{tabular}{|c|c|c|c|c|c|c|c|c|c|c|c|}
\hline Benzo(g,h,i)perylene & NS & $2 \times 10-4$ & $<0.01$ & $<0.01$ & $<0.01$ & $<0.01$ & $<0.01$ & $<0.01$ & $<0.01$ & $<0.01$ & $<0.01$ \\
\hline Indeno(1,2,3-d)pyrene & $5 \times 10-5$ & $2 \times 10-4$ & $<0.01$ & $<0.01$ & $<0.01$ & $<0.01$ & $<0.01$ & $<0.01$ & $<0.01$ & $<0.01$ & $<0.01$ \\
\hline
\end{tabular}

Table 5: Polyaromatic hydrocarbons profile of the groundwater analysis.

The mean $\mathrm{pH}$ during the month of June across the sampling points was $5.98 \pm 1.17$ (Table 6). It was however lower during the month of August with a mean of $4.11 \pm 0.039$. The same trend was observed for virtually all the parameters under study (EC, TDS, TH, BOD, COD, Bicarbonate, Carbonate, Chloride, Phosphate, Sulphate, Magnesium, Potassium, Sodium and Calcium). The physicochemical characteristics of groundwater in Ebubu community vary and were higher during the month of August than in the month of June and are supported by the findings of Uzoekwe and Oghosanime [51].

\begin{tabular}{|c|c|c|c|}
\hline \multirow[b]{2}{*}{ Parameters } & \multirow[b]{2}{*}{ Variables } & \multicolumn{2}{|l|}{ Month of collection } \\
\hline & & June (BH1-BH10) & August (BH1-BH10) \\
\hline \multirow[b]{2}{*}{$\mathrm{pH}$} & Mean & $5.983 \pm 1.172$ & $4.11 \pm 0.039$ \\
\hline & Range & $4.3-7.46$ & $4.05-4.18$ \\
\hline \multirow[b]{2}{*}{ Conductivity } & Mean & $219.47 \pm 160.48$ & $135.9 \pm 2.12$ \\
\hline & Range & $27-389$ & $134-140$ \\
\hline \multirow[b]{2}{*}{ TDS } & Mean & $131.66 \pm 96.2712$ & $76.34 \pm 14.3664$ \\
\hline & Range & $16.2-233$ & \\
\hline \multirow[b]{2}{*}{ Total Hardness } & Mean & $54.5 \pm 38.72$ & $24.07 \pm 2.05429$ \\
\hline & Range & $5.0-98.0$ & \\
\hline \multirow[b]{2}{*}{ BOD } & Mean & $11.75 \pm 7.374$ & $10 \pm 0$ \\
\hline & Range & $<0.50-20.0$ & $<0.50-10$ \\
\hline \multirow[b]{2}{*}{ COD } & Mean & $\mathrm{BDL} \pm \mathrm{BDL}$ & $21.63 \pm 3.008$ \\
\hline & Range & $\mathrm{BDL}$ & $<0.80-25.7$ \\
\hline \multirow[b]{2}{*}{ Bicarbonate } & Mean & $39.3 \pm 23.241$ & $\mathrm{BDL} \pm \mathrm{BDL}$ \\
\hline & Range & $<1.00-63.6$ & $\mathrm{BDL}$ \\
\hline \multirow[b]{2}{*}{ Carbonate } & Mean & $\mathrm{BDL} \pm \mathrm{BDL}$ & $\mathrm{BDL} \pm \mathrm{BDL}$ \\
\hline & Range & BDL & $\mathrm{BDL}$ \\
\hline \multirow[b]{2}{*}{ Chloride } & Mean & $68.95 \pm 50.40$ & $15.31 \pm 1.05$ \\
\hline & Range & $8.48-122$ & $14.3-17.5$ \\
\hline \multirow[b]{2}{*}{ Nitrate } & Mean & $0.41 \pm 0.883$ & $34.9 \pm 5.309$ \\
\hline & Range & $<0.02-0.63$ & $24.8-46.3$ \\
\hline \multirow[b]{2}{*}{ Phosphate } & Mean & $0.06 \pm 0.032$ & $0.055 \pm 0.025$ \\
\hline & Range & $<0.02-0.11$ & $<0.02-0.08$ \\
\hline \multirow[b]{2}{*}{ Sulphate } & Mean & $10.15 \pm 7.425$ & $4.178 \pm 0.499$ \\
\hline & Range & $1.25-18.0$ & $3.55-4.90$ \\
\hline Magnesium & Mean & $2.652 \pm 1.814$ & $2.04 \pm 0.051$ \\
\hline
\end{tabular}

\begin{tabular}{|l|l|l|l|}
\hline & Range & $0.43-4.68$ & $1.98-2.12$ \\
\hline \multirow{4}{*}{ Potassium } & Mean & $4.60 \pm 3.815$ & $3.80 \pm 0.095$ \\
\cline { 2 - 4 } & Range & $0.03-9.07$ & $3.64-3.93$ \\
\hline \multirow{3}{*}{ Sodium } & Mean & $11.57 \pm 8.793$ & $8.86 \pm 0.712$ \\
\cline { 2 - 4 } & Range & $1.40-21.3$ & $8.21-10.6$ \\
\hline \multirow{3}{*}{ Calcium } & Mean & $8.581 \pm 5.805$ & $5.844 \pm 0.446$ \\
\cline { 2 - 4 } & Range & $1.52-15.3$ & $5.37-6.57$ \\
\hline
\end{tabular}

Table 6: Summary of borehole water quality in Ebubu during the months of sampling.

Nickel, Lead and Cobalt had higher mean values of $0.098 \pm 0.168$, $0.088 \pm 0.085$ and $0.011 \pm 0.008$ respectively (Table 7) during the month of August than during the month of June, while Cadmium had higher mean value in August $0.106 \pm 0.009$. Lower values during the month of August may be due to more ionic dilution within the water aquifer because of increase rainfall and is in agreement with the findings of Iwegbue, Egobuez and Opuene [55] within the Niger Delta area, they also added that the sampling period variations in the levels of the heavy metals could be attributed to the difference in individual metals solubility, $\mathrm{pH}$, leaching by acid rain during the wet season and topography of the area. Toxic metals trend in groundwater samples is in the order $\mathrm{Cd}(0.106 \pm 0.009)>\mathrm{Pb}(0.0610 .001)>\mathrm{Ni}(0.048 \pm$ $0.023)>\operatorname{Co}(0.004 \pm 0.001)$ for the month of June (first sampling), and $\mathrm{Ni}(0.098 \pm 0.168)>\mathrm{Pb}(0.088 \pm 0.085)>\mathrm{Cd}(0.082 \pm 0.058)>\mathrm{Co}(0.011 \pm$ 0.008 ) for the month of August (second sampling) (Table 7). It was also observed that both $\mathrm{Cd}$ and $\mathrm{Pb}$ had values which were higher than the WHO [22] and NIS [23] permissible limits during both periods of sampling. While the value for Ni was only higher than the WHO [22] limits for the month of August. Co was within range for both sampling period.

\begin{tabular}{|l|l|l|l|}
\hline \multirow{2}{*}{ Parameters } & \multirow{2}{*}{ Variables } & Month of collection \\
\cline { 3 - 4 } & Mean & $0.048 \pm 0.023$ & $0.098 \pm 0.168$ \\
\hline \multirow{2}{*}{ Nickel } & Range & BDL-0.08 & BDL-0.005 \\
\hline \multirow{2}{*}{ Cadmium } & Mean & $0.106 \pm 0.009$ & $0.082 \pm 0.058$ \\
\hline \multirow{2}{*}{ Lead } & Range & $0.09-1.25$ & $0-0.08$ \\
\hline Cobalt & Mean & $0.061 \pm 0.001$ & $0.088 \pm 0.085$ \\
\cline { 2 - 4 } & Range & $0.06-0.31$ & $0.055-0.21$ \\
\hline
\end{tabular}




\begin{tabular}{|l|l|l|l|}
\hline & Range & BDL-0.003 & $0.00-0.02$ \\
\hline
\end{tabular}

Table 7: Summary of toxic metals in borehole water in Ebubu during the months of sampling.

The correlation coefficients ( $r$ ) matrixes for physicochemical parameters are presented in Table 8 . The $\mathrm{pH}$ value shows a strong positive correlation with total hardness (0.704), positive correlation with EC (0.584), TDS (0.584), $\mathrm{Ca}^{2+}(0.668), \mathrm{Na}^{+}(0.624), \mathrm{K}^{+}(0.565)$, $\mathrm{Cl}^{-}(0.582)$ and $\mathrm{SO}_{4}{ }^{2-}(0.581)$, but a weak positive correlation with $\mathrm{Mg}^{2+}(0.498)$. EC, on the other hand, shows a strong positive relationship with all the parameters considered having values above $90 \%$. All the parameters show strong correlation with one another with values above $90 \%$ except $\mathrm{pH}$ (Table 8 ). This shows that they all have a common source of pollution [56].

\begin{tabular}{|c|c|c|c|c|c|c|c|c|c|c|}
\hline & $\mathrm{pH}$ & EC & TDS & TH & $\mathrm{Cl}^{-}$ & $\mathrm{SO}_{4}{ }^{2-}$ & $\mathrm{Mg}^{2+}$ & $\mathrm{K}^{+}$ & $\mathrm{Na}^{+}$ & $\mathrm{Ca}^{2+}$ \\
\hline $\mathrm{pH}$ & 1 & & & & & & & & & \\
\hline EC & 0.584 & 1 & & & & & & & & \\
\hline TDS & 0.584 & 0.999 & 1 & & & & & & & \\
\hline TH & 0.704 & 0.979 & 0.979 & 1 & & & & & & \\
\hline $\mathrm{Cl}^{-}$ & 0.582 & 0.999 & 0.999 & 0.979 & 1 & & & & & \\
\hline $\mathrm{SO}_{4}{ }^{2-}$ & 0.581 & 0.999 & 0.999 & 0.979 & 0.999 & 1 & & & & \\
\hline $\mathrm{Mg}^{2+}$ & 0.498 & 0.954 & 0.955 & 0.944 & 0.956 & 0.959 & 1 & & & \\
\hline $\mathrm{K}^{+}$ & 0.565 & 0.937 & 0.937 & 0.895 & 0.935 & 0.93 & 0.808 & 1 & & \\
\hline $\mathrm{Na}+$ & 0.624 & 0.993 & 0.993 & 0.989 & 0.994 & 0.995 & 0.967 & 0.903 & 1 & \\
\hline $\mathrm{Ca}^{2+}$ & 0.668 & 0.987 & 0.987 & 0.991 & 0.988 & 0.989 & 0.946 & 0.921 & 0.991 & 1 \\
\hline
\end{tabular}

Table 8: Correlation of some selected physicochemical, anions and cations parameters of groundwater.

Also, the correlation analysis computed for the four toxic metals (Table 9) indicates that there is a strong positive relationship between Cobalt and Lead (0.603), indicating a possible common source of contamination to the sampled groundwater possibly the legacy oil spill site within the area of study. A positive relationship is revealed between Lead and Nickel (0.500), and a weak positive correlation (0.137) between Cobalt and Cadmium (Table 9). There was, however, a negative correlation between Nickel and Cadmium (-0.523) and between Nickel and Cobalt (-0.036), indicating that they do not have the same source of pollution [56].

\begin{tabular}{|l|l|l|l|l|}
\hline Metals & Nickel & Lead & Cobalt & Cadmium \\
\hline Nickel & 1 & & & \\
\hline Lead & 0.500 & 1.000 & & \\
\hline Cobalt & -0.036 & $0.603^{*}$ & 1.000 & \\
\hline Cadmium & -0.523 & -0.006 & 0.137 & 1.000 \\
\hline *Significant level $p>0.05$ & &
\end{tabular}

Table 9: Correlation between the toxic metals parameter of borehole water in Ebubu.

\section{Summary, Conclusions and Recommendations}

Standard analytical protocols were used to assess the quality of groundwater in Ebubu town, Eleme local government area of Rivers State, Nigeria. The groundwater samples were analysed for physicochemical variables, toxic metals contents and polycyclic aromatic hydrocarbons (PAHs) levels. Statistical tools like mean, standard deviation and correlation analysis were used for data analysis.

The values obtained for all the physicochemical parameters $(\mathrm{pH}$, EC, TDS, TSS, TH, BOD, $\mathrm{COD}, \mathrm{HCO}_{3}{ }^{-}, \mathrm{CO}_{3}{ }^{2-}, \mathrm{Cl}^{-}, \mathrm{NO}_{3}{ }^{-}, \mathrm{PO}_{4}{ }^{3-}, \mathrm{SO}_{4}{ }^{2-}$, $\mathrm{Na}^{+}, \mathrm{K}^{+}$) except $\mathrm{Ca}^{2+}$, and $\mathrm{Mg}^{2+}$, were below the maximum permissible limit prescribed by WHO [22] and NIS [23]. Magnesium (2.35 mg/L) and Calcium $(7.21 \mathrm{mg} / \mathrm{L})$ contents recorded exceeded the WHO [22] regulatory limit of $0.5 \mathrm{mg} / \mathrm{L}$ and $0.1 \mathrm{mg} / \mathrm{L}$, respectively. The physicochemical characteristics of groundwater in Ebubu community vary and are higher in August than in June.

The mean values of toxic metals examined: Nickel $(0.042 \mathrm{mg} / \mathrm{L})$, Cadmium $(0.361 \mathrm{mg} / \mathrm{L})$, Lead $(0.117 \mathrm{mg} / \mathrm{L})$ and cobalt $(0.010 \mathrm{mg} / \mathrm{L})$ exceeded the WHO [22] regulatory limit of $0.07 \mathrm{mg} / \mathrm{L} ; 0.361 \mathrm{mg} / \mathrm{L}$; $0.01 \mathrm{mg} / \mathrm{L}$ and $0.0038 \mathrm{mg} / \mathrm{L}$ respectively. These values also exceeded the permissible limit prescribed by NIS [23].

The values recorded for PAHs were all less than $1.00 \mathrm{mg} / \mathrm{L}$. The toxic metals levels examined also varied across the sampling periods; apart from $\mathrm{Cd}$ whose mean value was higher during the month of June, but lower in August, all other toxic metals (Ni, $\mathrm{Pb}$, and $\mathrm{Co}$ ) followed same trend with the physicochemical properties.

The correlation analysis for physicochemical parameters $(\mathrm{pH}, \mathrm{EC}$, TDS, Total Hardness, $\mathrm{Ca}^{2+}, \mathrm{Mg}^{2+}, \mathrm{Na}^{+}, \mathrm{K}^{+}, \mathrm{Cl}^{-}$and $\mathrm{SO}_{4}{ }^{2-}$ ) revealed that the $\mathrm{pH}$ value shows a strong positive correlation with total hardness (0.704), positive correlation with EC (0.584), TDS (0.584), $\mathrm{Ca}^{2+}$ (0.668), $\mathrm{Na}^{+}(0.624) \mathrm{K}^{+}(0.565), \mathrm{Cl}^{-}(0.582)$ and $\mathrm{SO}_{4}{ }^{2-}(0.581)$, but a weak positive correlation with $\mathrm{Mg}^{2+}(0.498)$. EC on the other hand, 
shows a strong positive relationship with all the parameters considered having values above $90 \%$ indicating a common source of pollution.

Also, the correlation analysis computed for the toxic metals suggests that there is a strong positive relationship between Cobalt and Lead (0.603), indicating a possible common source of contamination to the sampled groundwater possibly the legacy oil spill site within the area of study. A positive relationship between Lead and Nickel (0.500) was established, while Cobalt and Cadmium show a weak positive correlation (0.137). There was, however, a negative correlation between Nickel and Cadmium (-0.523) and between Nickel and Cobalt (-0.036), indicating that they do not have the same source of pollution.

From the results obtained from this study, the following conclusions have been made:

The values obtained for all the physicochemical parameters $(\mathrm{pH}$, EC, TDS, TSS, TH, BOD, COD, $\mathrm{HCO}_{3}{ }^{-}, \mathrm{CO}_{3}{ }^{2-}, \mathrm{Cl}^{-}, \mathrm{NO}_{3}{ }^{-}, \mathrm{PO}_{4}{ }^{3-}, \mathrm{SO}_{4}{ }^{2-}$, $\mathrm{K}^{+}, \mathrm{Na}^{+}, \mathrm{Mg}^{2+}$ and $\mathrm{Ca}^{2+}$ ) were not significant enough to have any pollution effect on the sampled water. The total mean level of cadmium $(0.361 \mathrm{mg} / \mathrm{L})$ was observed to be the highest of all heavy metals under study. The mean concentrations of nickel, cadmium, lead, and cobalt in the water samples were higher than the WHO [22] limits for drinking water. The sampled boreholes water is therefore not suitable for human consumption but may be adequate for domestic processes.

In light of the findings from this study, the following recommendations are made in an attempt to enhance and promote the quality and suitability of the water sources. Periodic analysis of samples of groundwater taken from boreholes should be routinely carried out as industrialization and population are on the increase in Ebubu town. Such analysis will reveal pollution status of groundwater in such area of interest. If the result of such analysis shows that there is excessive contamination of the water, there is the need to intimate the consumers and other users of the water to guard against the subsequent impact that may arise from such development.

\section{References}

1. WHO (2013) International Standards for Drinking Water (8th ed.) Geneva, pp. 36-38.

2. www.wateraid.org/waterfacts and figures (Accessed on: August 10, 2016).

3. Amangabara GT, Ejenma E (2012) Groundwater Quality Assessment of Yenagoa and Environs, Bayelsa State, Nigeria between 2010 and 2011. Resources and Environment 2: 20-29.

4. Mgbemena NM, Obodo GA, Okonkwo NA, Onwukeme BI (2014) Physicochemical Assessment of Borehole Waters in Ovim, Isiukwuato LGA, Abia State, Nigeria. Journal of Applied Chemistry 7: 31-33.

5. Adeyemi SO (1987) Water Policies for the Future. Convocation lecture. University of Maiduguri, Maiduguri, Nigeria.

6. Sule RO (2003) Fundamentals of Urban Planning Theory and Practice in Nigeria. Calabar. International Press, pp. 4-6.

7. Okeola OG, Salami AW (2014) Groundwater Resources in the Nigeria's Quest for United Nation's Millennium Development Goals (MDGs) and beyond. Journal of Sustainable Development in Africa 16: 57-71.

8. MacDonald AM, Taylor RG (2012) Quantitative maps of groundwater resources in Africa. Environmental Research Letters 7: 1-7.

9. Ezomo FO, Biose O, Ajieh MU (2013) Evaluation of Groundwater in Uromi, Edo State, Nigeria. International Journal of Scientific and Engineering Research 4: 3-4.

10. Ramakrishnaiah CR, Sadashivalah C, Ranganna G (2009) Assessment of Water Quality Index for the Groundwater in Tumkur Taluk, Karnataka State, India. Journal of Chemistry 6: 523-530.
11. Rajagopal R (1978) Impact of land-use on groundwater quality in Grand Transverse Bay region of Michigan. Journal of Environmental Quality 7: 93- 98.

12. Shiklomanov IA (1993) World Fresh Water Resource In: Gleick PH (Ed.) Water Crisis: A Guide to World Freshwater Resources, Oxford. Oxford University Press, pp. 10-11.

13. Shah T (2004) Groundwater and Human Development: Challenges and Opportunities in Livelihood and Environment, Proceedings Stockholm World Water Week, pp. 23-24.

14. Bunce NJ (2004) Environmental Chemistry. 2nd ed., Canada: Wuevz Publishing Ltd. Wininnipeg, pp. 20-25.

15. WHO (1996) State of the World Health Report Geneva, pp. 37-48.

16. Brandley DJ (1977) Health Aspect of Water Supplies in Tropical Countries. Oklahoma State University. USA. Annual Science Journal 33: 78-79.

17. Owabor CN, Ogbeide SE, Susu AA (2010) Estimation of transport and degradation parameters for Naphthalene and Anthracene: influence of mass transfer on kinetics. Environmental Monitoring and Assessment 169: 607-617.

18. Ritter L, Solomon K, Sibley P (2002) Sources, Pathways, and Relative Risks of Contaminants in Surface Water and Groundwater: A Perspective Prepared for the Walkerton Inquiry. Journal of Toxicology and Environmental Health 65: 1-142.

19. Okuo JM, Okonji EJ, Omoyerere FR (2007) Hydrophysiochemical Assessment of the Warri Coastal Aquifer, Southern Nigeria. Journal of Chemical Society of Nigeria 32: 53-64.

20. Umo AE, Okoye COB (2006) Quality of Borehole Waters in Nsukka Area, Enugu State Nigeria. Nigeria Annuals of Natural Sciences 6: 121-123.

21. ASTM (2003) Method for Examination of Water and Waste water. 20th ed. ASTM, pp. 110.

22. WHO (2006) International Standards for Drinking Water (3rd ed.) Geneva, pp. 346-385.

23. Nigerian Industrial Standard (NIS) (2007) Nigerian Standard for Drinking Water Quality, (NSDWQ) ICS 13.060.20. 554: 13-14.

24. Adoki A (2012) Soil and Groundwater Characteristics of a Legacy Spill Site. Journal of Applied Science and Environmental Management 16: 103-113.

25. Nwankwo CN, Igboekwe MU (2011) The Mineral Effects of Sedimentary Layers on Groundwater in Choba, Rivers State, Nigeria. The Pacific Journal of Science and Technology, Vol. 12.

26. Kupwade RV (2013) Pre and Post Monsoon Monitoring of Ground Water Quality in Region near Kupwad MIDC, Sangli, Maharashtra. International Journal of Chemical Technology Research 5: 2291-2294.

27. Fashola FI, Nwankwoala HO, Tse AC (2013) Physico-chemical characteristics of groundwater in Old Port Harcourt Township, Eastern Niger Delta. International Journal of Physical Sciences 1: 047-055.

28. Freeze RA, Cherry JA (1979) Groundwater. New Jersey: Prentice-Hall Inc. Englewood Cliffs, NJ, pp. 1-5.

29. Edet A, Okereke C (2001) A regional study of saltwater intrusion in southeastern Nigeria based on the analysis of geoelectrical and hydrochemical data. Environmental Geology 40: 1278-1289.

30. www.wqa.org./waterhardness.html (Accessed on: August 10, 2016).

31. Nwankwoala HO, Marshal HI, Oborie E (2013) Characterizations and Quantitative Indicators of Groundwater Quality in Okirika, Rivers State, Nigeria. International Journal of Science Inventions Today 2: 319-334.

32. Agbalagba OE, Alao AA (2011) Investigation into the physio-chemical properties and hydrochemical processes of groundwater from commercial boreholes in Yenagoa, Balyelsa State, Nigeria. African Journal of Environmental Science and Technology 5: 473-481.

33. Edet A, Nganje TN, Ukpong AJ, Ekwere AS (2011) Groundwater chemistry and quality of Nigeria: A Status Review. African Journal of Environmental Science and Technology 5: 1152-1169.

34. Davis SN, DeWiest RJ (1966) Hydrogeology. New York: Wiley and Sons, pp.53. 
Citation: Sokpuwu IA (2017) Groundwater Quality Assessment in Ebubu Community, Eleme, Rivers State, Nigeria. J Environ Anal Chem 4: 228. doi:10.4172/2380-2391.1000228

Page 11 of 11

35. Mason A (2001) Bicarbonates in Groundwater. Retrieved from: http:// pub.usgs.gov/wri/wri024045/htms/report2.htm. Accessed on: August 26, 2016.

36. Udom GJ, Etu-Efeotor JO, Esu EO (1999) Hydrogeochemical Characteristics of Groundwater in Parts of Port Harcourt and Tai-Eleme Local Government Areas. Global Journal Pure Applied Science 5: 545-552.

37. Nwala CO (2007) Physico-chemical Parameters of Monopumps and Well Waters in Igbo-Etche. Journal of Nigerian Environment and Society 4: 78-87.

38. Manilla PN, Tamuno-adoki T (2007) Physical and Chemical Assessment of Okirika River, Okirika LGA. Rivers State, Nigeria. Journal of Nigerian Environment and Society 4: 78-87.

39. NDDC (2004) Niger Delta Development Commission. Environment and Hydrology Study Report, pp. 60-136.

40. Rim-Rukeh OG, Ikhifa PA, Okokoyo JK, Odjighere MO (2007) PhysicoChemical Characteristics Of Borehole Water In Warri, Delta State, Nigeria, Agbor. Journal of Science Education (AJOSE), Vol. 3.

41. www.extoxnet.orst.edu.faqs/safedrink/phosphate in drinking water (n.d) (Accessed on: August 08, 2016).

42. Bolaji TA, Tse CA (2009) Spatial Variation in Groundwater Geochemistry and Water Quality Index in Port Harcourt. Scientia Africana 8: 134-155.

43. NDES-Niger Delta Environmental Survey (NDES) (2000) Niger Delta Development Priorities and Action Plan. Phase II Report, Vol. 2.

44. Ugwu SA, Nwosu JI (2009) Effect of Waste Dumps on Groundwater in Choba using Geophysical Method. Journal of Applied Science and Environmental Management 13: 85-89.

45. Fabis W (1987) Pollution load of soil impactor on soil and water quality Allg Color time very. BLV publishing company, Munich, pp. 128-131.

46. Asubiojo OI, Nkono NA, Ogunsua AO, Oluwole AF, Ward NI, et al. (1997) Trace elements in drinking and groundwater samples in Southern Nigeria. Science of the Total Environment 208: 1-8.
47. Akpoveta OV, Okoh BE, Osakwe SA (2011) Quality Assessment of Borehole Water used in the Vicinities of Benin, Edo State and Agbor, Delta State of Nigeria. Current Research in Chemistry 3: 62-69.

48. Lenntech (2010) Heavy Metals. Accessed on: July 12, 2015.

49. Alasia D, Wokoma F, Iyagba A (2009) Abstracts from the World Congress of Nephrology, May 22-26, 2009, Milan, Italy. NDT Plus 2: 1733.

50. Jarup L (2003) Hazards of heavy metals contamination. British Medical Bulletin 68: 167-182.

51. Uzoekwe AA, Oghosanine FF (2011) The effect of Refinery and Petrochemical Effluent on Water Quality of Ubeji Creek Warri, Southern Nigeria. Ethiopian Journal of Environmental Studies and Management 4: 107- 116 .

52. Sanders T, Buchner V (2009) Neurotoxic Effects and Biomarkers of Lead Exposure: A Review. Environmental Health 24: 15-45.

53. Ideriah TJK, Briggs OA, Stanley HO (2010) Bioaccumulation of Heavy Metals in Periwinkle from Lower Sombriero River, Nigeria. Nigeria Journal of Nigerian Environment and Society 5: 207-216.

54. Anyakora C, Coker H, Arbabi M (2011) Application of Polynuclear Aromatic Hydrocarbons in Chemical Fingerprinting: the Niger Delta Case study. Iranian Journal of Environmental Health and Scientific Engineering 8: 75-84.

55. Iwegbue CM, Egobuez FE, Opuene K (2006) Preliminary assessment of heavy metals levels of soils of an oil field in the Niger Delta, Nigeria. International Journal of Environmental Science and Technology 3: 167-172.

56. Tripathi B, Pandey R, Raghuvanshi D, Singh H, Pandey V, et al. (2014) Studies on the Physico-chemical Parameters and Correlation Coefficients of the River Ganga at Holy Place, Shringverpur Allahabad. Journal of Environmental Science, Toxicology and Food Technology 8: 29-36. 